\title{
Cultural Capital and English Language Achievement at Grade Three in Iranian High Schools
}

\author{
Ebrahim Khodadady \\ Ferdowsi University of Mashhad, International Branch, Mashhad, Iran \\ Marziye Mokhtary \\ Ferdowsi University of Mashhad, International Branch, Mashhad, Iran
}

\begin{abstract}
This study administered the Persian cultural capital scale (CCS) compiled by Khodadady and Natanzi (2012) to three hundred and ten grade three high school (G3HS) students. The subjection of the collected data to the principal axis factoring and rotating the extracted latent variables via Varimax with Kaiser Normalization produced nine factors, i.e., Cultural Investment, Religious Commitment, Artistic Appreciation, Cultural Visits, Cultural Commitment, Cultural Curiosity, Cultured Family, Literate Family, and Higher Education. These results showed that compared to university students, more factors underlie G3HS students' cultural capitals. Reliability and correlational analyses showed that not only the CCS itself but also its eight factors were reliable and most of them correlated significantly with each other. Although no significant relationship could be found between the CCS and scores on English as a foreign language (EFL), one of its underlying factors, i.e., Literate Family, correlated positively and significantly with the EFL. Another factor, i.e., Religious Commitment, however, revealed a negatively significant relationship with the EFL. Results are discussed and suggestions are made for future research.
\end{abstract}

Index Terms - culture, religion, family, foreign language

\section{INTRODUCTION}

The phrase cultural capital consists of two schemata, i.e., cultural and capital, which have proved to be of great educational importance not only to sociolinguists but also to sociologists. The semantic noun schema culture to which the morph $a l$ has been added to delineate its descriptive or adjectival role in the phrase, does not represent "whatever it is one has to know or believe in order to operate in a manner acceptable to its members and to do so in any role that they accept for any one of themselves" (Goodenough, 1657, p. 167). It does, however, refer to 'high culture' reflected in "the appreciation of music, literature, the arts, and so on" (Wardaugh, 1992, p. 217).

Capital as the second adjective schema constituting the phrase cultural capital stands for "any resource which confers an advantage on those who hold it and which, further, can be accumulated and passed on through mechanisms of inheritance" (Bennett \& Silva, 2011, p. 430). Having a library at home is, for example, considered as an indicator of cultural capital which can be used by grade three high school (G3HS) students to achieve their educational objectives better than their peers in the field of secondary education.

Although Ayre (2012) took an extreme position and asserted that "there has been little agreement as to how cultural capital should be measured, or even if it can be measured" (p. 2), a number of studies have developed questionnaires (e.g., Sullivan, 2001) or employed qualitative approaches such as in-depth interviews (e.g., Devine, 2004) to explore what factors underlie cultural capital and whether the factors have had any significant relationships with variables such as reading ability and General Certificate of Secondary Education (GCSE) exams.

Jæger (2009), for example, employed the data collected from 2,234 students aged 15 by Danish PISA (Programme for International Student Assessment) survey and analysed them via a customized empirical model and found a significant correlation between the respondents' reading ability and parents' stock of cultural capital such as home educational resources $(\mathrm{r}=.05, p<.01)$, cultural communication, i.e., often children report that their parents discuss 1$)$ political or social issues and 2) books, films or television programs with them, $(\mathrm{r}=.26, p<.001)$, family socioeconomic status ( $\mathrm{r}=.007, p<.001)$, father's level of education ( $\mathrm{r}=.08, p<.001)$, and mother's level of education $(\mathrm{r}=.09, p<.001)$.

A review of literature shows that few studies, if any, have attempted to develop a reliable measure to explore the latent variables underlying cultural capital in given contexts. As Carter (2003) convincingly argued, cultural capital is context-specific. This often-neglected feature of psychological measures necessitates their validation in various societies where variables explored by these measures interact with each other differently. Khodadady and Golparvar (2011), for example, showed that while two factors underlie the religious orientation scale developed by Allport and Ross (1967) in America, it increases to four in Iran. 
Khodadady and Natanzi (2012) [henceforth $K \& N$ ] were among the first researchers who reviewed the literature in general and Lareau and Weininger's (2003) study in particular, selected the most salient cultural indicators, and added them to those already selected by Khodadady and Zabihi (2011) and Khodadady, Alee and Natanzi (2011) and developed the first cultural capital scale (CCS) in Mashhad, Iran.

K\&N administered their 31-item Persian CCS to 381 English students of five universities. When they applied the Principal Axis Factoring to their data and rotated the results via Varimax with Kaiser Normalization, they extracted eight factors underlying the university students' cultural capital, i.e., Cultured Family, Cultural Commitment, Cultural Investment, Religious Commitment, Cultural Visits, Literary and Art Studies, Art Appreciation, and Literate Family, and concluded that cultural capital is not a unitary construct.

The present study is designed to find out whether the administration of the K\&N's CCS to G3HS students will result in extracting the same number of factors. In addition to exploring the factorial validity of the CCS with the participants of a homogeneous age and educational level, the study aims to find out whether there is any significant relationship between the G3HS students' cultural capital and their achievement in English as a foreign language (EFL).

\section{Methodology}

\section{A. Participants}

Three hundred and ten G3HS students, $170(54.8 \%)$ female and $140(45.2 \%)$ male, took part in the study voluntarily. They had registered as full time students at Zeynabiyeh, Allameh, Allameh Tabtabaii and Narjess girls' schools in districts two and three and Sheikh Ansari Shahed. Imam Ali, Jamaran and Private Mafakher boys' high schools in districts one, five and six of Mashhad education bureaus. Their age ranged between 16 and $19($ Mean $=17.13, \mathrm{SD}=.47)$ and they spoke Persian $(\mathrm{n}=307,99 \%)$, Lori $(\mathrm{n}=1, .3 \%)$, Turkish $(\mathrm{n}=1, .3 \%)$, and Arabic $(\mathrm{n}=1, .3 \%)$ as their mother language.

\section{B. Instruments}

A bio data questionnaire, cultural capital scale and overall sores on English achievement were used in the study.

Bio data questionnaire

A bio data questionnaire consisting of five short answer open-ended questions dealing with the students' school name, educational district, gender and age was used to collect demographic information.

Cultural Capital Scale

The Persian cultural capital scale compiled and validated by K\&N was employed in this study. It consists of thirty one cultural indicators specified by a number of researchers. (Interest readers are suggested to consult the K\&N for a brief description of sources from which the indicators have been taken.) Each indicator is presented on a five-point Likert scale requiring the participant to indicate whether they always, usually, often, seldom or never did a certain type of cultural activity such as listening to music. The values of 5, 3, 2, and 1 were then assigned to these five points to quantify the elicited responses, respectively.

Overall scores on English

Since the questionnaires employed in this study were administered at the end of school year in Iran, the EFL teachers were asked to write down the overall score of each student on English. The score is formally reported out of twenty as the average of scores obtained by students contributions to the discussions brought up in the class, quizzes held during the year, and final written examination measuring the students grammar and vocabulary knowledge as well as reading comprehension ability.

\section{Procedure}

Upon having the bio data and the Persian CCS copied, the second author who teaches English as a foreign language (EFL) in high schools herself contacted the EFL teachers in the specified seven schools and asked them to encourage their students to take part in the project. Upon their approval, she attended the classes on previously specified dates, administered the questionnaires in person and answer the participants' questions and concerns. Since both measures were in Persian, no serious questions were raised as regards the content of cultural indicators and they were thus administered under standard conditions. The participants were asked to hand in their completed questionnaires to their teacher who wrote their English scores in a specified slot by checking their records.

\section{Data Analysis}

For determining the well functioning of indicators comprising the Persian CCS their descriptive statistics were calculated. The reliability of the CCS was then estimated to ensure that it yields a stable measure of cultural capital among the G3HS students. The cultural capital indicators were then subjected to Principal Axis Factoring and the factors extracted were rotated via Varimax with Kaiser Normalization to determine what latent variables underlie the students' cultural capital. For determining the number of factors, eigenvalues of one and higher were adopted as criteria.

The descriptive statistics and reliability of the factors extracted were also estimated to have a better picture of their functioning. The factors were then correlated with each other to find out whether they had any significant relationships with each other. The CCS and its factors were finally correlated with the G3HS students' English scores to determine 
whether they were related to each other. The descriptive as well as inferential statistics were estimated via IBM SPSS Statistics 19.0 to test the five hypotheses below.

H1. The CCS will be a reliable measure of cultural capital.

$\mathrm{H} 2$. The factors underlying the CCS will be reliable.

H3. The factors underlying the CCS will correlate significantly with each other.

H4. The CCS will correlate significantly with the G3HS students' scores on English.

H5. The factors underlying the CCS will correlate significantly with the G3HS students' scores on English.

\section{Results AND Discussion}

Table 1 presents the descriptive statistics and the reliability coefficient of the CCS administered in this study and those of K\&N. (The descriptive statistics of indicators comprising the CCS is given in Appendix.) As can be seen, the alpha reliability coefficient of the CCS in this study is 0.84 , confirming the first hypothesis that the CCS will be a reliable measure of cultural capitals. The coefficient is, however, slightly lower than the one reported by K\&N for university students, i.e., 0.86, which might be attributed to the difference in the number of participants in the two studies.

TABLE 1

DESCRIPTIVE STATISTICS AND RELIABILITY COEFFICIENT OF THE CCS

\begin{tabular}{|l|l|l|l|l|l|}
\hline CCS & N & No of loading items & Mean & SD & Alpha \\
\hline Present study & 310 & 30 & 87.42 & 15.959 & .84 \\
\hline K\&N & 381 & 29 & 90.40 & 16.707 & .86 \\
\hline
\end{tabular}

Table 2 presents the Kaiser-Meyer-Olkin (KMO) Measure of Sampling Adequacy of this and K\&N's studies, i.e., 0.80 and 0.83 , respectively. As can be seen, both KMO statistics are in the .80 s, indicating that the sample selected in the study was as "meritorious" (DiLalla \& Dollinger 2006, p. 250) as that of K\&N. As it can also be seen, the significant Bartlett's Test of Sphericity, i.e., $\mathrm{X}^{2}=2449.014$, $\mathrm{df}=465, p<.001$, showed that the correlation matrix was not an identity matrix.

TABLE 2

KMO AND BARTLETT'S TEST

\begin{tabular}{|l|l|l|l|}
\hline \multicolumn{2}{|l|}{} & \multicolumn{1}{l|}{ This study } & \multicolumn{1}{l|}{ K\&N } \\
\hline \multicolumn{2}{|l|}{ Kaiser-Meyer-Olkin Measure of Sampling Adequacy } & .798 & .830 \\
\hline Bartlett's Test of Sphericity & Approx. Chi-Square & 2449.014 & 4016.835 \\
\cline { 2 - 4 } & df & 465 & 465 \\
\cline { 2 - 4 } & Sig. & .000 & .000 \\
\hline
\end{tabular}

Table 3 presents the initial communalities (IC) and extracted communalities (EC) obtained from the 31 CC indicators in this and K\&N studies. As can be seen, the lowest extraction communalities in the studies are .21 (Items 6 and 24 ) and .18 (Items 6 and 26), respectively. These results do not support Costello and Osborne's (2005) suggestion of .40 as the lowest acceptable communality. They do, however, support K\&N's acceptance of any communality whose item loads acceptably on a factor. It is also suggested in this study that regardless of its EC magnitude, any item loading negatively on a factor be considered as non-contributive to the construct under study.

TABLE 3

INITIAL COMMUNALITIES (IC) AND EXTRACTED COMMUNALITIES (EC) OBTAINED VIA PAF

\begin{tabular}{|c|c|c|c|c|c|c|c|c|c|c|c|c|c|c|}
\hline \multirow{2}{*}{ Item } & \multicolumn{2}{|c|}{ This study } & \multicolumn{2}{|l|}{$\mathrm{K} \& \mathrm{~N}$} & \multirow{2}{*}{ Item } & \multicolumn{2}{|c|}{ This study } & \multicolumn{2}{|c|}{$K \& N$} & \multirow{2}{*}{ Item } & \multicolumn{2}{|c|}{ This study } & \multicolumn{2}{|c|}{$\mathrm{K} \& \mathrm{~N}$} \\
\hline & IC & EC & IC & $\mathrm{EC}$ & & IC & EC & IC & EC & & IC & EC & IC & $\mathrm{EC}$ \\
\hline I1 & .46 & .56 & .34 & .39 & $\mathrm{I} 12$ & .38 & .44 & .47 & .54 & $\mathrm{I} 23$ & .34 & .61 & .32 & .29 \\
\hline $\mathrm{I} 2$ & .50 & .59 & .37 & .56 & $\mathrm{I} 13$ & .29 & .29 & .47 & .49 & I24 & .32 & .33 & .31 & .33 \\
\hline I3 & .32 & .34 & .34 & .35 & I14 & .40 & .51 & .49 & .57 & $\mathrm{I} 25$ & .20 & .21 & .26 & .23 \\
\hline I4 & .46 & .59 & .46 & .54 & I15 & .43 & .49 & .49 & .53 & I26 & .25 & .29 & .46 & .54 \\
\hline I5 & .42 & .61 & .50 & .75 & I16 & .24 & .26 & .42 & .50 & I27 & .26 & .27 & .25 & .18 \\
\hline I6 & .19 & .21 & .20 & .18 & I17 & .21 & .24 & .35 & .37 & I 28 & .27 & .36 & .39 & .51 \\
\hline I7 & .29 & .29 & .33 & .30 & $\mathrm{I} 18$ & .32 & .60 & .57 & .59 & I29 & .26 & .43 & .25 & .30 \\
\hline I8 & .51 & .62 & .51 & .55 & I19 & .25 & .32 & .61 & .70 & I30 & .30 & .30 & .39 & .41 \\
\hline I9 & .44 & .50 & .51 & .51 & I 20 & .18 & .31 & .43 & .49 & I31 & .57 & .65 & .60 & .66 \\
\hline I10 & .55 & .67 & .62 & .76 & I21 & .21 & .24 & .38 & .41 & & .52 & .65 & .52 & .56 \\
\hline I11 & .28 & .50 & .37 & .45 & I 22 & & & & & & & & & \\
\hline
\end{tabular}

Item one, I like to listen to music, for example, has the ECs of .39 and loads acceptably on factors four (-.32) and seven (.51), respectively, in K\&N's study. However, K\&N ignored the negative loading on factor four and adopted the positive and acceptable loading of .51 on factor seven as the main contribution of the item to this factor. In contrast, as shown in Table 4, the same item loads negatively only on factor two, indicating that whatever the factor represents, item one does it in the opposite direction. For this very reason it was treated as non-contributive in this study. Similarly, item 
two loads negatively on factor two (-.55). It does, nonetheless, load positively on factor three (.40) and this very positive loading renders it as a constituting indicator of factor three only.

TABLE 4

ROTATED FACTORS UNDERLYING THE CCS

\begin{tabular}{|c|c|c|c|c|c|c|c|c|c|c|c|c|c|c|c|c|c|c|c|}
\hline \multirow{2}{*}{ Item } & \multicolumn{9}{|c|}{ Factors } & \multirow{2}{*}{ Item } & \multicolumn{9}{|c|}{ Factors } \\
\hline & 1 & 2 & 3 & 4 & 5 & 6 & 7 & 8 & 9 & & 1 & 2 & 3 & 4 & 5 & 6 & 7 & 8 & 9 \\
\hline I01 & $*$ & -.62 & $*$ & $*$ & $*$ & $*$ & $*$ & $*$ & * & I17 & $*$ & $*$ & $*$ & $*$ & $*$ & $*$ & .35 & $*$ & $*$ \\
\hline I02 & $*$ & -.55 & .40 & $*$ & $*$ & $*$ & $*$ & $*$ & $*$ & I18 & $*$ & $*$ & $*$ & $*$ & $*$ & $*$ & .75 & $*$ & $*$ \\
\hline I03 & $*$ & $*$ & .46 & $*$ & $*$ & $*$ & $*$ & $*$ & .30 & I19 & $*$ & $*$ & $*$ & $*$ & $*$ & $*$ & .50 & $*$ & $*$ \\
\hline I04 & $*$ & $*$ & $*$ & .69 & $*$ & $*$ & $*$ & $*$ & $*$ & $\mathrm{I} 20$ & $*$ & $*$ & $*$ & $*$ & $*$ & $*$ & $*$ & $*$ & .47 \\
\hline I05 & $*$ & $*$ & $*$ & .71 & $*$ & $*$ & $*$ & $*$ & $*$ & I21 & $*$ & $*$ & $*$ & $*$ & .31 & $*$ & $*$ & $*$ & $*$ \\
\hline I06 & $*$ & .30 & $*$ & $*$ & $*$ & $*$ & $*$ & $*$ & $*$ & $\mathrm{I} 22$ & $*$ & $*$ & $*$ & $*$ & .74 & $*$ & $*$ & $*$ & $*$ \\
\hline I07 & .40 & $*$ & $*$ & $*$ & $*$ & $*$ & $*$ & $*$ & $*$ & I23 & $*$ & $*$ & * & $*$ & .42 & .31 & * & $*$ & $*$ \\
\hline I08 & .71 & $*$ & $*$ & $*$ & $*$ & $*$ & $*$ & * & $*$ & I24 & $*$ & $*$ & $*$ & $*$ & .33 & $*$ & $*$ & $*$ & $*$ \\
\hline I09 & $\begin{array}{l}.61 \\
\end{array}$ & $*$ & $*$ & $*$ & $*$ & $*$ & * & * & * & I25 & $*$ & .41 & * & $*$ & $*$ & * & * & $*$ & * \\
\hline $\mathrm{I10}$ & \begin{tabular}{|l|}
.76 \\
\end{tabular} & $*$ & $*$ & $*$ & $*$ & $*$ & $*$ & $*$ & $*$ & I26 & $*$ & $*$ & $*$ & $*$ & $*$ & .32 & $*$ & $*$ & $*$ \\
\hline I11 & $*$ & $*$ & $*$ & $*$ & $*$ & .65 & $*$ & $*$ & $*$ & I27 & $*$ & $*$ & * & $*$ & $*$ & $*$ & $*$ & .49 & $*$ \\
\hline $\mathrm{I} 12$ & .33 & $*$ & $*$ & $*$ & $*$ & .48 & $*$ & * & $*$ & I28 & $*$ & $*$ & * & $*$ & * & $*$ & * & .62 & $*$ \\
\hline I13 & * & $*$ & $*$ & $*$ & $*$ & .30 & * & * & $*$ & I29 & .36 & $*$ & .33 & $*$ & $*$ & $*$ & $*$ & $\begin{array}{l}* \\
\end{array}$ & $*$ \\
\hline $\mathrm{I14}$ & $*$ & .65 & $*$ & $*$ & $*$ & $*$ & $*$ & $*$ & $*$ & I30 & $*$ & $*$ & .68 & $*$ & $*$ & $*$ & $*$ & $*$ & $*$ \\
\hline I15 & $*$ & .67 & $*$ & $*$ & $*$ & $*$ & $*$ & * & $*$ & I31 & $*$ & $*$ & .72 & $*$ & $*$ & $*$ & $*$ & $*$ & $*$ \\
\hline I16 & $*$ & .37 & $*$ & $*$ & $*$ & * & $*$ & $*$ & $*$ & & & & & & & & & & \\
\hline
\end{tabular}

Table 5 presents the descriptive statistics of the nine rotated factors underlying the CCS. As can be seen, the alpha RCs of eight factors range from .50 to .74 , largely confirming the second hypothesis that the factors underlying the CCS will be reliable. While factors one and four have the highest $\mathrm{RC}$, i.e., $\alpha=.74$ and .72 , respectively, factor four has the lowest, $\alpha=.50$, which might be attributed to the fewness of its constituting items and lower standard deviation as compared to factor four comprising the same number of items.

TABLE 5

DESCRIPTIVE STATISTICS OF THE NINE ROTATED FACTORS UNDERLYING THE CCS

\begin{tabular}{|c|c|c|c|c|c|c|c|c|}
\hline $\mathbf{F}$ & Name & $\begin{array}{l}\text { \# of } \\
\text { item }\end{array}$ & Mean & SD & Skewness & Kurtosis & $\begin{array}{l}\text { Variance } \\
\text { explained }\end{array}$ & Alpha \\
\hline 1 & Cultural Investment & 5 & 14.07 & 5.145 & .119 & -.852 & 7.464 & .74 \\
\hline 2 & Religious Commitment & 5 & 14.06 & 3.826 & .240 & -.321 & 6.783 & .65 \\
\hline 3 & Artistic Appreciation & 4 & 11.09 & 4.011 & .134 & -.654 & 6.195 & .70 \\
\hline 4 & Cultural Visits & 2 & 5.23 & 2.029 & .499 & -.202 & 4.233 & .72 \\
\hline 5 & Cultural Commitment & 4 & 11.63 & 3.691 & .047 & -.432 & 4.189 & .57 \\
\hline 6 & Cultural Curiosity & 4 & 9.47 & 3.384 & .427 & -.421 & 4.086 & .60 \\
\hline 7 & Cultured Family & 3 & 12.57 & 2.157 & -1.364 & 2.381 & 4.001 & .53 \\
\hline 8 & Literate Family & 2 & 4.81 & 1.882 & .602 & .210 & 3.257 & .50 \\
\hline \multirow[t]{2}{*}{9} & Higher Education & 1 & 4.49 & 1.114 & -2.618 & 6.705 & 2.464 & - \\
\hline & CCS & 30 & 87.42 & 15.959 & .154 & -.144 & 42.673 & .84 \\
\hline
\end{tabular}

Table 6 presents five items, i.e., I07, I08, I09, I10, and I29, comprising Cultural Investment as the first factor. As can be seen, most of its items load on the third factor for university students with item I29 loading on a different factor, indicating that Cultural Investment is of first priority for G3HS students. Out of 42.7 it explains $7.464 \%$ of variance in the scale and shows the highest significant correlation with the sixth factor called Cultural Curiosity, i.e., $r=.45, \mathrm{p}<.01$, in this study.

TABLE 6

INDICATORS LOADINGS ON CULTURAL INVESTMENT AS THE FIRST FACTOR (F)

\begin{tabular}{|l|l|l|l|l|}
\hline \multirow{2}{*}{ Item } & \multirow{2}{*}{ Loading } & \multicolumn{2}{|c|}{ K\&N } & \multirow{2}{*}{ Indicator } \\
\cline { 3 - 4 } & & F & Loading & I \\
\hline I10 & .76 & 3 & .85 & I buy lots of books, study and keep them in my library. \\
\hline I08 & .71 & 3 & .68 & I have extracurricular study in my leisure time \\
\hline I09 & .61 & 3 & .69 & I have personal library in my room and add new books to that. \\
\hline I07 & .40 & 3 & .39 & I have library membership \\
\hline I29 & .36 & 6 & .49 & I am interested in literature and poetry and have literal study \\
\hline
\end{tabular}

Table 7 presents the loadings of items I06, I14, I15, I16 and I25 constituting the second factor, i.e., Religious Commitment, underlying the G3HS students' cultural capital. This factor occupies the fourth position for university students whose Religious Commitment does not involve eating in traditional eateries. Out of 42.7 it explains $6.78 \%$ of variance in the scale and correlates he highest with the sixth factor, i.e., Cultural Curiosity, i.e., $\mathrm{r}=.26, p<.01$, in this study. 
TABLE 7

INDICATORS LOADINGS ON RELIGIOUS COMMITMENT AS THE SECOND FACTOR (F)

\begin{tabular}{|c|c|c|c|c|}
\hline \multirow{2}{*}{ Item } & \multirow{2}{*}{ Loading } & \multicolumn{2}{|c|}{$\mathbf{K} \& \mathbf{N}$} & \multirow{2}{*}{ Indicator } \\
\hline & & $\mathbf{F}$ & Loading & \\
\hline $\mathrm{I} 15$ & .67 & 4 & .67 & I attend commentary classes on the Quran and Hadith. \\
\hline $\mathrm{I} 25$ & .41 & 4 & .66 & While traveling, I prefer to visit shrines of Imam's offspring \\
\hline I16 & .37 & 4 & .58 & I visit the holy shrine of Imam Reza regularly. \\
\hline I06 & .30 & - & - & I prefer to eat in traditional eateries than in fast food restaurant. \\
\hline
\end{tabular}

Table 8 presents items I02, I03, I30 and I31 loading acceptably on factor three, Artistic Appreciation. As can be seen, while items 30 and 31 along with item 29 contribute to university students' sixth factor, Literary and Art Studies, items I01, I02 and I03 constitute their seventh factor, Artistic Appreciation as found by K\&N. The loadings of these items on a single factor for G3HS students shows that some cultural factors become more distinct over years and education. Out of 42.7 it explains $6.2 \%$ of variance in the scale and correlates the highest with Cultural Visits, i.e., r $=.41, \mathrm{p}<.01$, establishing the closest relationship between the two factors.

TABLE 8

INDICATORS LOADINGS ON ARTISTIC APPRECIATION AS THE THIRD FACTOR (F)

\begin{tabular}{|l|l|l|l|l|}
\hline \multirow{2}{*}{ Item } & \multirow{2}{*}{ Loading } & \multicolumn{2}{|l|}{ K\&N } & \multirow{2}{*}{ Indicator } \\
\cline { 3 - 4 } & & $\mathbf{F}$ & Loading & \\
\hline I31 & .72 & 6 & .45 & I attend art courses. \\
\hline I30 & .68 & 6 & .54 & I visit art exhibitions \\
\hline I03 & .46 & 7 & .38 & I enjoy watching theatres on TV. \\
\hline I02 & .40 & 7 & .71 & I like to attend art courses and play an instrument. \\
\hline
\end{tabular}

Table 9 presents items I04 and I05 loading acceptably on factor four, Cultural Visits. As can be seen, the same items load on the same factor for university students and thus reveal the factorially confirmed constant nature of Cultural Visits over years and education. Out of 42.7 it explains $4.2 \%$ of variance in the scale and correlates the highest with Cultural Investment i.e., $\mathrm{r}=.54, \mathrm{p}<.01$, followed by Artistic Appreciation i.e., $\mathrm{r}=.41, p<.01$, emphasizing the significant role cultural investment and visits play in helping G3HS students appreciate arts.

TABLE 9

CULTURAL CAPITAL INDICATORS LOADINGS ON CULTURAL VISITS AS THE FOURTH FACTOR (F)

\begin{tabular}{|l|l|l|l|l|}
\hline \multirow{2}{*}{ Item } & \multirow{2}{*}{ Loading } & \multicolumn{2}{|l|}{ K\&N } & \multirow{2}{*}{ Indicator } \\
\cline { 3 - 4 } & & $\mathbf{F}$ & Loading & \\
\hline I05 & .709 & 5 & .83 & I visit handy-craft galleries. \\
\hline I04 & .692 & 5 & .68 & I visit museum and historical places. \\
\hline
\end{tabular}

Table 10 presents the four items, i.e., I21, I22, I23 and I24, loading acceptably on factor five called Cultural Commitment by K\&N. As can be seen, I22 has a much higher loading on this factor for G3HS students (.74) than university students (.46), indicating that internet is playing a more significant role in the Cultural Commitment of the former than the latter. Out of 42.7 it explains $4.2 \%$ of variance in the scale and correlates the highest with Cultural Curiosity i.e., $\mathrm{r}=.37, p<.01$.

TABLE 10

INDICATORS LOADINGS ON CULTURAL COMMITMENT AS THE FIFTH FACTOR (F)

\begin{tabular}{|l|l|l|l|l|}
\hline \multirow{2}{*}{ Item } & \multirow{2}{*}{ Loading } & \multicolumn{2}{|l|}{ K\&N } & \multirow{2}{*}{ Indicator } \\
\cline { 3 - 4 } & & F & Loading & \\
\hline I22 & .741 & 2 & .46 & I use internet for doing my different official works. \\
\hline I23 & .420 & 2 & .52 & I visit news and political websites \\
\hline I24 & .329 & 1 & .30 & I attend sport classes \\
\hline I21 & .308 & 2 & .50 & I watch documentaries on TV \\
\hline
\end{tabular}

Table 11 presents items I11, I12, I13, and 126 loading acceptably on factor six, Cultural Curiosity extracted in this study. As can be seen, three out of four of its constituting items load on Cultural Commitment for university students, indicating that culture loses its attractive nature as the students leave high schools. Cultural Curiosity involves not only buying newspaper and reading scientific magazines, but also solving cross-word puzzles which disappears when the students enter universities. Out of 42.7 it explains $4.1 \%$ of variance in the scale and correlates the highest with $C u l t u r a l$ Investment i.e., $\mathrm{r}=.45, p<.01$. 
TABLE 11

INDICATORS LOADINGS ON CULTURAL CURIOSITY AS THE SIXTH FACTOR (F)

\begin{tabular}{|c|c|c|c|c|}
\hline \multirow{2}{*}{ Item } & \multirow{2}{*}{ Loading } & \multicolumn{2}{|c|}{$\mathbf{K} \& \mathbf{N}$} & \multirow{2}{*}{ Indicator } \\
\hline & & $\mathbf{F}$ & Loading & \\
\hline I11 & .654 & 2 & .60 & I buy newspapers regularly every day. \\
\hline I26 & .316 & - & - & I solve cross-word puzzles in my free time \\
\hline I13 & .302 & 2 & .56 & I study cultural part of the magazines \\
\hline
\end{tabular}

Table 12 presents items I17, I18, and I19 loading acceptably on factor seven, Cultured Family. As can be seen, G3HS students are striving towards establishing themselves as worthy members of society because Item I18 confirming their being a cultured person has the highest loading (.75) on the factor whereas for university students it shifts to their being grown up in a cultured family (.78). Out of 42.7, factor seven explains $4 \%$ of variance in the CCS and correlates the highest with Cultural Investment i.e., $\mathrm{r}=.27, p<.01$.

TABLE 12

INDICATORS LOADINGS ON CULTURED FAMILY AS THE SEVENTH FACTOR

\begin{tabular}{|l|l|l|l|l|}
\hline \multirow{2}{*}{ Item } & \multirow{2}{*}{ Loading } & \multicolumn{2}{|l|}{ K\&N } & \multirow{2}{*}{ Indicator } \\
\cline { 3 - 4 } & & F & Loading & \\
\hline I18 & .745 & 1 & .74 & I am a cultured person \\
\hline I19 & .503 & 1 & .78 & I have grown up in a cultured family \\
\hline I17 & .351 & 1 & .54 & I have fluency in my speech and others understand me easily \\
\hline
\end{tabular}

Table 13 presents items I27 and I28 loading acceptably on the eighth factor, Literate Family. As can be seen, the highest loading item indicates the ability of G3HS students' parents to communicate in English (.62) whereas parents' studying in leisure time loads the highest for university students (.59), indicating that compared to the past, more and more parents are learning English as a language of communication in Iran. Out of 42.7, it explains 3.3\% of variance in the scale and correlates the highest with Artistic Appreciation i.e., $\mathrm{r}=.29, p<.01$.

TABLE 13

INDICATORS LOADINGS ON LITERATE FAMILY AS THE EIGHTH FACTOR

\begin{tabular}{|c|c|c|c|c|}
\hline \multirow{2}{*}{ Item } & \multirow{2}{*}{ Loading } & \multicolumn{2}{|c|}{$\mathbf{K} \& \mathbf{N}$} & \multirow{2}{*}{ Indicator } \\
\hline & & $\mathbf{F}$ & Loading & \\
\hline $\mathrm{I} 28$ & 618 & 8 & .50 & My parents can communicate in English \\
\hline I27 & .490 & 8 & .59 & My parents study in their leisure time \\
\hline
\end{tabular}

Table 14 presents the only indicator, i.e., I20, which loads acceptably on the ninth factor called Higher Education in this study. As can be seen, this item loads on the first factor, Cultured Family, for university students, indicating that G3HS students view higher education as a single and distinct factor whose pursuing becomes their main goal. Out of 42.7 it explains $2.5 \%$ of variance in the scale and correlates the highest with Cultural Investment i.e., $\mathrm{r}=.18, p<.01$, emphasizing the primary role of Cultural Investment and Cultured Family in the lives of G3HS and university students, respectively.

TABLE 14

THE INDICATOR LOADINGS ON HIGHER EDUCATION AS THE NINTH FACTOR (F)

\begin{tabular}{|c|c|c|c|c|}
\hline \multirow{2}{*}{ Item } & \multirow{2}{*}{ Loading } & \multicolumn{2}{|c|}{ K\&N } & \multirow{2}{*}{ Indicator } \\
\hline & & $\mathbf{F}$ & Loading & \\
\hline $\mathrm{I} 20$ & .466 & 1 & .60 & I like to continue my education to higher level \\
\hline
\end{tabular}

Table 15 presents the correlation coefficients obtained between the 30-item CCS, its nine factors and English achievement scores. As can be seen, out of 36 coefficients, 29 (81\%) are significant and thus confirm the third hypothesis that the factors underlying the CCS will correlate significantly with each other to a large extent. Among the nine factors, Religious Commitment does not show significant relationships with Artistic Appreciation, Cultured Family, and Literate Family, implying that religious families may not approve with nonreligious arts, discourage their children's fluency in speech and avoid communication in English. Similarly, pursuing Higher Education does not significantly relate to Cultural Visits, Commitment and Curiosity, indicating that G3HS students who intend to continue their studies are more focused on their school studies and employ their family to achieve their goal. 
TABLE 15

CORRELATIONS BETWEEN THE 30-ITEM CCS, ITS NINE FACTORS AND ENGLISH SCORES

\begin{tabular}{|c|c|c|c|c|c|c|c|c|c|c|}
\hline \multirow{2}{*}{ Factors and English } & \multirow{2}{*}{ CCS } & \multicolumn{9}{|c|}{ Factors } \\
\hline & & 1 & 2 & 3 & 4 & 5 & 6 & 7 & 8 & 9 \\
\hline 1 Cultural Investment & $.76^{* *}$ & 1 & $.23 * *$ & $.37 * *$ & $.33 * *$ & $.32 * *$ & $.45^{* *}$ & $.27 * *$ & $.25 * *$ & $.18 * *$ \\
\hline 2 Religious Commitment & $.46^{* *}$ & $.23 * *$ & 1 & .01 & $.18 * *$ & $.23 * *$ & $.26 * *$ & .09 & -.09 & $.13^{*}$ \\
\hline 3 Artistic Appreciation & $.63 * *$ & $.37 * *$ & .01 & 1 & $.41 * *$ & $.31 * *$ & $.32 * *$ & $.19 * *$ & $.29 * *$ & $.14 *$ \\
\hline 4 Cultural Visits & $.54 * *$ & $.33 * *$ & $.18 * *$ & $.41 * *$ & 1 & $.26 * *$ & $.29 * *$ & .06 & $.19 * *$ & .06 \\
\hline 5 Cultural Commitment & $.64 * *$ & $.32 * *$ & $.23 * *$ & $.31 * *$ & $.26 * *$ & 1 & $.37 * *$ & $.23 * *$ & $.23 * *$ & .11 \\
\hline 6 Cultural Curiosity & $.68 * *$ & $.45 * *$ & $.26 * *$ & $.32 * *$ & $.29 * *$ & $.37 * *$ & 1 & $.25 * *$ & $.16^{* *}$ & .03 \\
\hline 7 Cultured Family & $.44 * *$ & $.27 * *$ & .09 & $.19 * *$ & .06 & $.23 * *$ & $.25 * *$ & 1 & $.20 * *$ & $.17 * *$ \\
\hline 8 Literate Family & $.40 * *$ & $.25 * *$ & -.09 & $.29 * *$ & $.19 * *$ & $.23 * *$ & $.16^{* *}$ & $.20 * *$ & 1 & $.16^{* *}$ \\
\hline 9 Higher Education & $.28 * *$ & $.18 * *$ & $.13 *$ & $.14 *$ & .06 & .11 & .03 & $.17 * *$ & $.16^{* *}$ & 1 \\
\hline English Scores & .01 & .02 & $-.17^{* *}$ & -.03 & -.02 & .07 & -.02 & .09 & $.20^{* *}$ & .07 \\
\hline
\end{tabular}

** Correlation is significant at the 0.01 level (2-tailed)

* Correlation is significant at the 0.05 level (2-tailed)

As it can be seen in Table 15, learning English as a foreign language (EFL) in high schools does not show any significant relationship with cultural capital and thus disconfirm the fourth hypothesis that the CCS will correlate significantly with the G3HS students' scores on English. It does not correlate significantly with seven factors, either. Seventy eight percent of the results presented in Table 15 disconfirm the fifth hypothesis that the factors underlying the CCS will correlate significantly with the G3HS students' scores on English, questioning the generally held assumption that language and culture are closely related, especially within a context where the EFL is taught as a part of national curriculum.

English achievement, however, correlates significantly with Literate Family $(\mathrm{r}=.20, p<.01)$ and Religious Commitment $(\mathrm{r}=-.17, p<.01)$. These results reveal the important role parents play in their G3HS children's learning of the EFL, explaining four percent of variance in their achievement. They also show that the more religiously committed the G3HS students are, the lower their scores will be on the EFL test, calling for a national EFL policy to explore the relationship more thoroughly and change the direction to a positive one.

\section{CONCLUSION}

The CCS developed by K\&N and employed in the present study is a reliable and valid measure of cultural capital which can be employed to improve the quality of secondary and higher education for several reasons. First, its 31 indicators contribute to different factors underlying the CCS depending on the age and educational level of participants. While listening to music, for example, loads on university students' Artistic Appreciation, it does not load acceptably on any of the nine factors underlying the G3HS students' cultural capital, indicating that it is only higher education which helps university students appreciate music as part of their cultural capital. In contrast, only G3HS students solve cross-word puzzles as part of their Cultural Curiosity whereas such an action lacks relevance to university students' cultural capital in Mashhad.

Secondly, pursuing Higher Education reveals itself as a distinct factor for G3HS students whereas it forms a part of Cultured Family for university students. In other words, Higher Education loses its appeal as a distinct underlying variable of cultural capital and fades into Cultured Family once students enter university. For the G3HS students, however, pursuing Higher Education shows the highest significant relationships with their Cultural Investment followed by Cultured Family, reflecting its priority among these students' parents.

Thirdly, factors underlying the CCS vary in the percentages of variances they explain in the cultural capital of the members of a given society as they grow developmentally and educationally. While Cultural Investment explains the highest percentage in the G3HS students' cultural capital, Cultured Family does the same for university students. The difference highlights the distinct role of static and relational cultural capitals established by Tramonte and Willms (2010). Static cultural capital "is an expression of the family's socioeconomic advantage" reflected in their Cultural Investment. Cultured Family, however, behaves as an aspect of relational cultural capital in that it "embodies the resources and experiences of children that they can use in society to interact strategically and successfully in achieving their goals" (p. 201).

Fourthly, age and educational level contribute to the relationship between the factors underlying the CCS. The highest significant relationship is, for example, found between the Cultural Investment and Cultural Curiosity for G3HS students. For university students, however, the same relationship exists between Cultured Family and Literate Family, indicating that static cultural capital plays a more important role in G3HS students' life if only the factors underlying the CCS are taken into account. However, it is the Literate Family, i.e., an index of G3HS student' relational cultural capital, which relates positively to the EFL achievement.

And finally, achievement in the EFL shows significant relationships with two factors underling the CCS, i.e., Religious Commitment and Literate Family, though in opposite directions. The findings of this study show that the more religiously committed the G3HS students are, the less they achieve in the EFL, implying that religion-friendly EFL syllabi are needed to reverse the direction. They also indicate that among the nine factors underlying the CCS, the 
parents are the pivot upon which the relational cultural capital operates to help G3HS students achieve their best in the EFL. Future research must show whether this relationship holds equally true for other grades in high schools and universities.

\section{APPENDiX The DescriPTive STATISTICS OF ITEMS COMPRISING THE CCS ( $=310)$}

\begin{tabular}{|c|c|c|c|c|c|c|c|c|c|c|}
\hline Item & Mean & SD & Skewness & Kurtosis & $\begin{array}{l}\text { Missing } \\
\%\end{array}$ & $\begin{array}{l}\text { Never } \\
\%\end{array}$ & $\begin{array}{l}\text { Seldom } \\
\%\end{array}$ & $\begin{array}{l}\text { Sometimes } \\
\%\end{array}$ & $\begin{array}{l}\text { Often } \\
\%\end{array}$ & $\begin{array}{l}\text { Always } \\
\%\end{array}$ \\
\hline I01 & 4.09 & 1.143 & -1.121 & .400 & 0 & 3 & 8 & 15 & 22 & 51 \\
\hline I02 & 3.30 & 1.582 & -.360 & -1.369 & 1 & 22 & 9 & 16 & 17 & 34 \\
\hline $\mathrm{I} 03$ & 2.44 & 1.270 & .532 & -.627 & 1 & 28 & 28 & 24 & 10 & 9 \\
\hline I04 & 2.83 & 1.103 & .168 & -.394 & 1 & 8 & 33 & 32 & 18 & 8 \\
\hline I05 & 2.40 & 1.188 & .475 & -.345 & 2 & 20 & 39 & 19 & 13 & 6 \\
\hline I06 & 3.07 & 1.353 & -.057 & -1.080 & 1 & 14 & 21 & 25 & 19 & 20 \\
\hline I07 & 2.94 & 1.510 & .019 & -1.295 & 2 & 20 & 22 & 17 & 16 & 23 \\
\hline I08 & 3.02 & 1.313 & -.128 & -.913 & 2 & 12 & 24 & 22 & 25 & 15 \\
\hline I09 & 2.72 & 1.676 & .229 & -1.537 & 2 & 35 & 15 & 12 & 11 & 26 \\
\hline $\mathrm{I} 10$ & 2.36 & 1.364 & .617 & -.772 & 1 & 33 & 28 & 14 & 13 & 11 \\
\hline I11 & 2.09 & 1.286 & 1.005 & -.031 & 1 & 44 & 26 & 14 & 7 & 9 \\
\hline $\mathrm{I12}$ & 2.67 & 1.202 & .168 & -.661 & 1 & 17 & 28 & 29 & 17 & 8 \\
\hline I13 & 2.69 & 1.339 & .279 & -.985 & 1 & 21 & 28 & 21 & 16 & 13 \\
\hline I14 & 2.17 & 1.162 & .740 & -.301 & 1 & 34 & 33 & 16 & 12 & 4 \\
\hline I15 & 2.15 & 1.164 & .682 & -.503 & 0 & 38 & 26 & 20 & 11 & 4 \\
\hline I16 & 3.52 & .988 & -.277 & -.417 & 0 & 2 & 13 & 33 & 35 & 17 \\
\hline I17 & 3.84 & \begin{tabular}{|l|}
1.046 \\
\end{tabular} & -1.091 & 1.434 & 1 & 1 & 9 & 17 & 44 & 27 \\
\hline I18 & 4.27 & \begin{tabular}{|l|}
.899 \\
\end{tabular} & -1.564 & 3.283 & 1 & 0 & 4 & 9 & 37 & 49 \\
\hline I19 & 4.46 & 1.060 & -2.411 & 5.678 & 1 & 3 & 2 & 5 & 18 & 70 \\
\hline $\mathrm{I} 20$ & 4.49 & 1.114 & -2.618 & 6.705 & 3 & 1 & 3 & 6 & 13 & 75 \\
\hline $\mathrm{I} 21$ & 3.52 & 1.367 & -.698 & -.310 & 3 & 6 & 13 & 22 & 25 & 31 \\
\hline $\mathrm{I} 22$ & 2.37 & 1.373 & .487 & -.960 & 1 & 36 & 20 & 19 & 14 & 9 \\
\hline I23 & 2.49 & \begin{tabular}{|l|}
1.443 \\
\end{tabular} & .465 & -1.126 & 1 & 34 & 22 & 15 & 15 & 14 \\
\hline $\mathrm{I} 24$ & 3.25 & 1.386 & -.241 & -.955 & 2 & 9 & 22 & 23 & 19 & 26 \\
\hline I25 & 3.16 & 1.256 & -.084 & -.962 & 0 & 11 & 20 & 29 & 21 & 18 \\
\hline I26 & 2.03 & \begin{tabular}{|l|}
1.200 \\
\end{tabular} & .940 & .069 & 1 & 42 & 27 & 16 & 8 & 5 \\
\hline $\mathrm{I} 27$ & 3.14 & 1.227 & -.151 & -.902 & 0 & 12 & 19 & 28 & 26 & 15 \\
\hline $\mathrm{I} 28$ & 1.67 & 1.072 & 1.536 & 1.889 & 2 & 58 & 23 & 8 & 5 & 4 \\
\hline I29 & 3.04 & 1.444 & -.030 & -1.240 & 1 & 17 & 21 & 21 & 17 & 23 \\
\hline $\mathrm{I} 30$ & 2.78 & 1.326 & .181 & -1.025 & 0 & 21 & 22 & 27 & 16 & 14 \\
\hline I31 & 2.57 & 1.346 & .346 & -1.045 & 0 & 28 & 23 & 22 & 16 & 11 \\
\hline
\end{tabular}

\section{REFERENCES}

[1] Allport, G. W., \& Ross, J. M. (1967). Personal religious orientation and prejudice. Journal of Personality and Social Psychology, 5, 447-457.

[2] Ayre, J. (2012). Cultural and linguistic capital, standardized tests and the perpetuation of educational inequalities. Unpublished MA thesis, the University of British Columbia.

[3] Bennett, T., \& Silva, E. (2011). Introduction: Cultural capital-histories, limits, prospects. Poetics, $39,427-443$. doi:10.1016/j.poetic.2011.09.008.

[4] Carter, P. L. (2003). "Black" cultural capital, status positioning, and schooling conflicts for low-income African American youth. Social Problems, 50(1), 136-155.

[5] Costello, A. B. \& Osborne, J. W. (2005). Best practices in exploratory factor analysis: Four recommendations for getting the most from your analysis. Practical Assessment Research \& Evaluation, 10(7), 1-9. Retrieved January 27, 2009 from http://pareonline.net/pdf/v10n7.pdf.

[6] Devine, F. (2004). Class Practices. Cambridge: Cambridge University Press.

[7] Goodenough, W. H. (1957). Cultural anthropology and linguistics. In P. L. Garvin (ed.), Report of the Seventh Round Table Meeting on Linguistics and Language Study. Washington, DC: Georgetown University Press.

[8] Jæger, M. M. (2009). Equal access but unequal outcomes: Cultural capital and educational choice in a meritocratic society, Social Forces, 87(4), June 2009, pp. 1943-1971. DOI: 10.1353/sof.0.0192.

[9] Khodadady, E., \& Golparvar, E. (2011). Factors underlying religious orientation scale: a methodological approach. Ilahiyat Studies: A Journal on Islamic and Religious Studies, 2(2), 215-235.

[10] Khodadady, E., \& Zabihi, R. (2011). Social and Cultural Capital: Underlying Factors and Their Relationship with the School Achievement of Iranian University Student. International Education Studies, 4(2), 63-71. doi:10.5539/ies.v4n2p63.

[11] Khodadady, E., Alaee, F. F., \& Natanzi, M. (2011). Factors underlying the social and cultural capitals of high school students and their relationship with English achievement. Theory and Practice in Language Studies, 1 (11), 1618-1627. doi:10.4304/tpls.1.11.1618-1627. 
[12] Lareau, A., \& Weininger, E. B. (2003). Cultural capital in educational research: A critical assessment. Theory and Society, 32, 567-606.

[13] Sullivan A. (2001). Cultural capital and educational attainment. Sociology 35(4): 893-912.

[14] Tramonte, L. \& Willms, L. J. D. (2010). Cultural capital and its effects on education outcomes. Economics of Education Review, 29, 200-213.

[15] Wardaugh, R. (1992). An introduction to sociolinguistics (2nd ed.). Oxford: Blackwell.

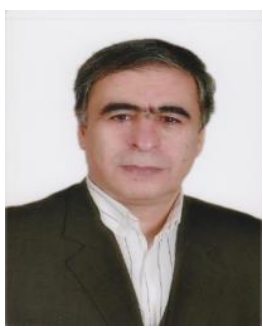

Ebrahim Khodadady was born in Iran in 1958. He obtained his $\mathrm{PhD}$ in Applied Linguistics from the University of Western Australia in 1998. He holds TESL Ontario and Canadian Language Benchmarks Placement Test (CLPBPT) certificates and has taught English as a first, second and foreign language to high school and university students in Australia, Canada and Iran.

He is currently an academic member of English Language and Literature Department at Ferdowsi University of Mashhad, Iran. He was invited as a VIP by Brock University in Canada in 2004 and served as the Associate Director of Assessment Center at George Brown College in Toronto for almost a year. His published books are Multiple-Choice Items in Testing: Practice and Theory (Tehran, Rahnama, 1999), Reading Media Texts: Iran-America Relations (Sanandaj, Kurdistan University, 1999) and English Language Proficiency Course: First Steps (Sanandaj, Kurdistan University, 2001). His main research interests are Testing, Language Learning and Teaching.

Dr. Khodadady is currently a member of Teaching English Language and Literature Society of Iran (TELLSI), TESL Ontario and European Society for Translation Studies. He is on the editorial board of Ferdowsi Review: An Iranian Journal of TESL, Literature and Translation Studies and has reviewed some research papers for Iranian Journal of Applied Linguistics and TESL Canada Journal as a guest reviewer.

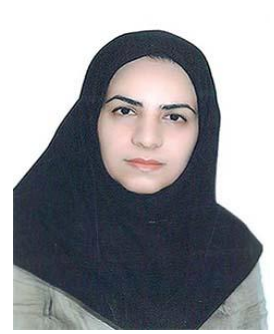

Marziye Mokhtary was born in Iran in 1974. She obtained her B.A in Teaching English as a Foreign Language from Sistan and Baluchistan University in 1997. She is currently an MA student of TEFL in International Branch of Ferdowsi University of Mashhad.

She has taught English as a foreign language in high schools in Mashhad to different levels for 15 years. She has been the member of English Language Department at Education Department of Mashhad since 2008. 